[17] Amorati, R., Foti, M. C., Valgimigli, L. (2013). Antioxidant Activity of Essential Oils. Journal of Agricultural and Food Chemistry, 61 (46), 10835-10847. doi: http://doi.org/10.1021/jf403496k

[18] Zhang, X., Guo, Y., Guo, L., Jiang, H., Ji, Q. (2018). In Vitro Evaluation of Antioxidant and Antimicrobial Activities of Melaleuca alternifolia Essential Oil. BioMed Research International, 2018, 1-8. doi: http://doi.org/10.1155/2018/2396109

[19] Gonzalez-Burgos, E., Gomez-Serranillos, M. P. (2012). Terpene Compounds in Nature: A Review of Their Potential Antioxidant Activity. Current Medicinal Chemistry, 19 (31), 5319-5341. doi: http://doi.org/10.2174/092986712803833335

[20] Nishimuta, K., Ito, Y. (2003). Effects of metronidazole and tinidazole ointments on models for inflammatory dermatitis in mice. Archives of Dermatological Research, 294 (12), 544-551. doi: http://doi.org/10.1007/s00403-002-0381-4

[21] Malchenko, O. A., Anisimova, L. V., Fedosov, M. I., Kubyshkin, A. V. (2014). The state of protooxidant-antioxidant system of the blood and muscular tissue of rats at experimental reperfusion syndrome. Taurian Medical and Biological Gazette, 17 (2 (66)), 90-93.

[22] Dolzhykova, O. V., Maloshtan, L. M. (2014). Eksperymentalne vyvchennya protyzapalnykh vlastyvostei novykh supozytoriyiv vaginalnykh «Melanizol». Problems of ecology and medicine genetics and clinical immunology. Kyiv; Lugansk, 4 (124), 161-166.

[23] Dolzhykova, O. V. Maloshtan, L. M. (2016). Microbiological predication of vaginal suppositories "Melanizol” using for nonspecific vaginitis treatment. Ukrainian biopharmaceutical journal, 3 (44), 20-23. doi: http://doi.org/10.24959/ ubphj.16.34

\title{
METHODOLOGY FOR ASSESSING THE LOGISTICS POTENTIAL OF THE FOREIGN ECONOMIC ACTIVITY OF A PHARMACEUTICAL COMPANY
}

\author{
Natali Zakharko \\ Department of Processes and Devices of chemical-pharmaceutical manufactures ${ }^{1}$ \\ paft@nuph.edu.ua \\ Rita Sahaidak-Nikitiuk \\ Department of Processes and Devices of chemical-pharmaceutical manufactures ${ }^{l}$ \\ Sagaidak_rita@ukr.net \\ Nataliya Demchenko \\ Department of Organization and Economics of Pharmacy \\ ${ }^{1}$ National University of Pharmacy \\ 53 Pushkinskay str., Kharkiv, Ukraine, 61002 \\ economica@nuph.edu.ua
}

\footnotetext{
Abstract

The aim of the article is to determine the essence of the logistics potential of a foreign trade activity of a pharmaceutical enterprise and justify the methods for determining it.

The materials used in the study include statistical data of the investigated pharmaceutical enterprises, namely JSC FF "Darnitsa", PJSC NPC "Borschagovsky Chemical and Pharmaceutical Plant”, PJSC "Pharmak”, LLC "FC Zdorovia” and JSC "Lekhim-Kharkiv". The study used methods of analysis and synthesis, generalization, content analysis, questionnaires and methods for assessing potential. The questionnaire was used to select indicators that should be part of the logistics potential of a foreign trade activity of a pharmaceutical enterprise.
} 
The experts were 100 leading specialists of pharmaceutical companies. They are all involved in foreign economic activity. Experts are gender-divided into women ( $73 \%$ ), men ( $27 \%)$; by age: up to 25 years $-8 \%, 25-35$ years - $14 \%$, 35-45 years - $27 \%$, $45-55$ years $-36 \%$, over 55 years $-15 \%$; by experience: up to 5 years $-11 \%, 5-10$ years $-15 \%, 10-20$ years $-32 \%, 20-30$ years $-36 \%$, over 30 years $-6 \%$. The experts' conclusions are valid, the coefficient of concordance is 0.86 , and the Pearson test exceeds the table value.

The essence of the definition of "potential of logistics of pharmaceutical enterprise's foreign trade activity" is investigated. The types of logistics potential of foreign economic activity and indicators that are appropriate to use for determining the level of development of the logistic potential in foreign economic activity are offered.

The potential of logistics of foreign trade activities of pharmaceutical enterprises consists of the potentials of logistics in the field of export and import. The system of indicators for measuring the logistics potential of a foreign trade activity of a pharmaceutical enterprise contains indicators selected through content analysis and questionnaires.

The method of estimation of logistics potential in foreign economic activity of pharmaceutical enterprise is offered.

Keywords: potential, logistics, foreign economic activity, pharmaceutical enterprise.

DOI: $10.21303 / 2504-5679.2019 .00997$

\section{Introduction}

In the current dynamic conditions, among the main causes of exacerbation of problems with the sale of pharmaceutical products, reducing the cost of production and marketing of drugs and increase its efficiency, scientists highlight the restructuring of the world economy, the intense development of the pharmaceutical market, the growing role of economic unions (alliances) and the activation of economic ties between pharmaceutical companies, suppliers of active pharmaceutical ingredients, basic and auxiliary materials, distribution oramy, active dissemination of new information and communication technology and logistics, change directions and volumes of international cargo and complexity of production processes, enterprises themselves inside and outside, that is, foreign economic activity.

Correctly built foreign economic activity of the enterprise due to the formation and support of business relations at the international level will bring him additional economic benefits. But it must be taken into account that the enterprise should carry out this activity only in those countries and with that partner that are the most profitable for a specific period of time.

Domestic pharmaceutical enterprises are distinguished by their unique geographical location at the crossroads of trade routes, therefore they can receive significantly more benefits from globalization and international cooperation. This predetermines the need to develop effective approaches to managing the processes of purchasing, transportation, storage and marketing of products, actualizes the need to use a scientific approach to improving the economic and organizational mechanism for the development of logistics processes in managing the movement of material, financial and information flows.

Theorists and practitioners [1,2] have already repeatedly proved that today it is logistics that provides the appropriate level of enterprise potential, together with natural conditions, resources, means and values, provides opportunities for more complete use of resources and, consequently, economic development for gaining competitive advantages in the market environment. So, it is quite clear that logistics from fundamental science is gradually turning into the practical dominant of the pharmaceutical enterprise, and the effective use of logistics tools can reduce costs, improve productivity and improve customer service. Using logistics approaches allows enterprises to carry out productive activities, and increases the role of the logistics component in the process of rational capacity building.

The aim of the article is to determine the essence of the logistics potential of the foreign economic activity of a pharmaceutical company and the rationale for its determination.

\section{Materials and methods}

The materials used in the study include statistical data of the investigated pharmaceutical enterprises, namely JSC FF “Darnitsa”, PJSC NPC "Borschagovsky Chemical and Pharmaceutical Plant", PJSC "Pharmak", LLC "FC Zdorovia” and JSC "Lekhim-Kharkiv". 
The study used methods of analysis and synthesis, generalization, content analysis, questionnaires and methods for assessing potential.

The experts were 100 leading specialists of pharmaceutical companies involved in foreign economic activity, among which women $-73 \%$, men $-27 \%$. According to age, the experts were divided as follows: up to 25 years old $-8 \%, 25-35$ years old $-14 \%$, 35-45 years old - $27 \%$, 45-55 years old $-36 \%$, over 55 years old $-15 \%$. According to the experience, experts were divided - up to 5 years $-11 \%, 5-10$ years $-15 \%, 10-20$ years $-32 \%, 20-30$ years $-36 \%$, over 30 years $-6 \%$. Expert conclusions are justified, the concordance coefficient is 0.86 , the Pearson criterion exceeds the table value.

The questionnaire was used to select indicators that should be part of the logistics potential of a foreign trade activity of a pharmaceutical enterprise. Score was scored on a ten-point scale ranging from the lowest (1 point) to the highest (10 points). Indicators with a weighted average of the expert evaluation score less than 3 were not used in the subsequent calculations.

\section{Experimental procedures.}

The study was conducted in five stages. At the first stage, based on the study of the opinions of scientists and the specifics of the pharmaceutical sector of the healthcare industry and the activity of pharmaceutical enterprises, the definition of "logistics potential of foreign economic activity of the pharmaceutical enterprise" was defined. The second stage is devoted to the study of the logistics potential composition of the foreign economic activity of a pharmaceutical company, which was carried out on the basis of content analysis and questionnaires. The third stage is an assessment of the logistics potential of the foreign economic activity of a pharmaceutical company. The fourth stage is devoted to determining the factors influencing it. In the fifth stage, the development of an optimal strategy for developing the logistics potential of foreign economic activity of the pharmaceutical enterprise was done.

\section{Results}

The analysis of publications on this range of issues indicates that there is little scientific work in the field. A number of issues remain under-researched, such as: theoretical substantiation of the essence of the logistics potential of a pharmaceutical enterprise (PhE), especially those that are subjects of foreign economic activity [3, 4]; lack of a unified systematic approach to the mechanism of its formation [5], operation and development, lack of applied development of organizational measures to optimize the management of logistics potential $[6,7]$.

In foreign publications, the potential is mostly regarded as a resource, but, for the most part, relative to a country or region (military, industrial, natural) [8,9], only some [10, 11] understand the degree of power (hidden opportunities) in any respect. Domestic economic literature $[12,13]$, on the contrary, is more inclined to understand it as opportunities, available forces, reserves and means that can be used to achieve a specific goal of the enterprise [14, 15]. However, some scholars $[16,17]$ argue that the potential is more properly called the set necessary for the functioning and development of a system of different types of resources. Therefore, despite the diversity of views on the essence of the concept and based on the general features of each interpretation, we can agree that the potential, in any case, means the presence of someone (person, staff, enterprise, society) hidden to activities in certain areas that have not yet emerged $[17,18]$.

Home authors, considering the functional features and structure of logistic processes by subject characteristics (personnel logistics, logistics of materials and finished goods, energy and information flows), determine the logistical potential of the enterprise as the maximum productivity (functional capacity) of systemically integrated subdivisions, all subdivisions, in space and time movement of personnel, materials and finished products, energy and information flows $[19,20]$.

The place of the FEA logistics potential in the structure of the PhE logistics potential in a formalized form is reflected as follows: 


$$
\left\{\begin{array}{l}
\mathrm{P}_{\text {IFEA }} \equiv \mathrm{f}\left\{\mathrm{P}_{1-\text { exp }} ; \mathrm{P}_{\text {l-imp }}\right\} ; \\
\mathrm{P}_{\text {IFEA }} \equiv \mathrm{f}\left\{\mathrm{A}_{\text {prod }} ; \mathrm{B}_{\text {warehouse }} ; \mathrm{C}_{\text {tr }} ; \mathrm{D}_{\text {purch }} ; \mathrm{l}_{\text {pal }} ; \mathrm{F}_{\text {inf }} ; \mathrm{H}_{\text {pers }} ; \mathrm{K}_{\text {serv }}\right\} \\
\mathrm{P}_{\text {IFEA }} \supset \mathrm{P}_{1-\exp } \wedge \mathrm{P}_{\text {LFEA }} \cap \mathrm{P}_{1-\text { exp }} \because \mathrm{P}_{1-\text { imp }} \supset \mathrm{A}_{\mathrm{B}} \wedge \mathrm{P}_{1-\text { imp }} \neq \mathrm{A}_{\mathrm{B}} ; \\
\mathrm{P}_{1 \text {-imp }} \supset \mathrm{B}_{\text {warehouse }} \wedge \mathrm{P}_{1-\text { imp }} \neq \mathrm{B}_{\text {warehouse }} ;
\end{array}\right.
$$

$\mathrm{P}_{1 \mathrm{FEA}}$ - many components of the logistics potential of foreign economic activity of a pharmaceutical company; $\mathrm{P}_{\text {l-exp }}$ and $\mathrm{P}_{\text {l-imp }}$ - a set of components of the logistics activity potential in the pharmaceutical export import sphere respectively; $\mathrm{A}_{\text {prod }}, \mathrm{B}_{\text {warehouse }}, \mathrm{C}_{\text {tr }}, \mathrm{D}_{\text {purch }}, \mathrm{I}_{\text {sal }}, \mathrm{F}_{\text {inf }}, \mathrm{H}_{\text {pers }}, \mathrm{K}_{\text {serv }}$ - set of elements in the structure of the potential of logistics activity in the field of export and import of the pharmaceutical enterprise, respectively, which is represented by the potential of production, warehouse, transport, purchasing, sales, information, personnel and logistics services.

Foreign Trade Logistics Potential is composed of export and import logistics. The system of indicators for measuring the logistics potential of the FEA of a pharmaceutical enterprise is shown in Fig. 1. The scorecard includes indicators selected through content analysis and questionnaire surveys.

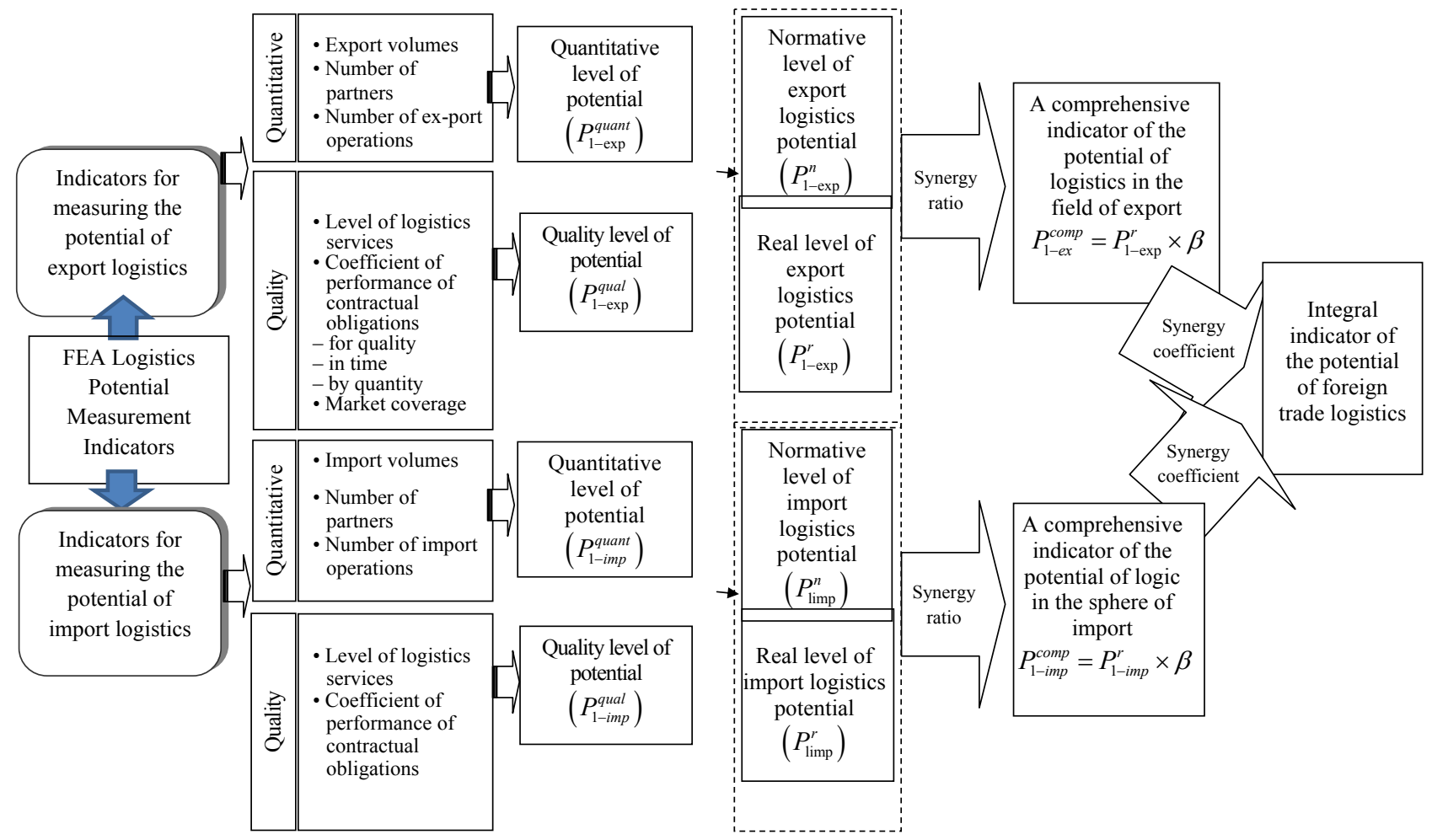

Fig. 1. System of indicators of measuring the potential of logistics of pharmaceutical enterprise FEA

Based on the calculated synergy coefficient, the enterprise monitors potential development in order to quickly respond to negative trends. The value of the synergy coefficient is in the range from $0<\beta<1$. If the estimated $\beta>1$, then the enterprise for a certain time has become more efficient in managing its potential. If $0.8<\beta<1$, then it is necessary to take measures to improve logistics. If $0.79<\beta$, then it is necessary to take strict measures for the efficient functioning of logistics and the enterprise as a whole.

The norm is the best level of $\mathrm{PhE}$ logistics potential for a certain period of time.

The dynamics of the logistics indicators of foreign economic activity of the studied $\mathrm{PhE}$ are shown in Fig. 2. 


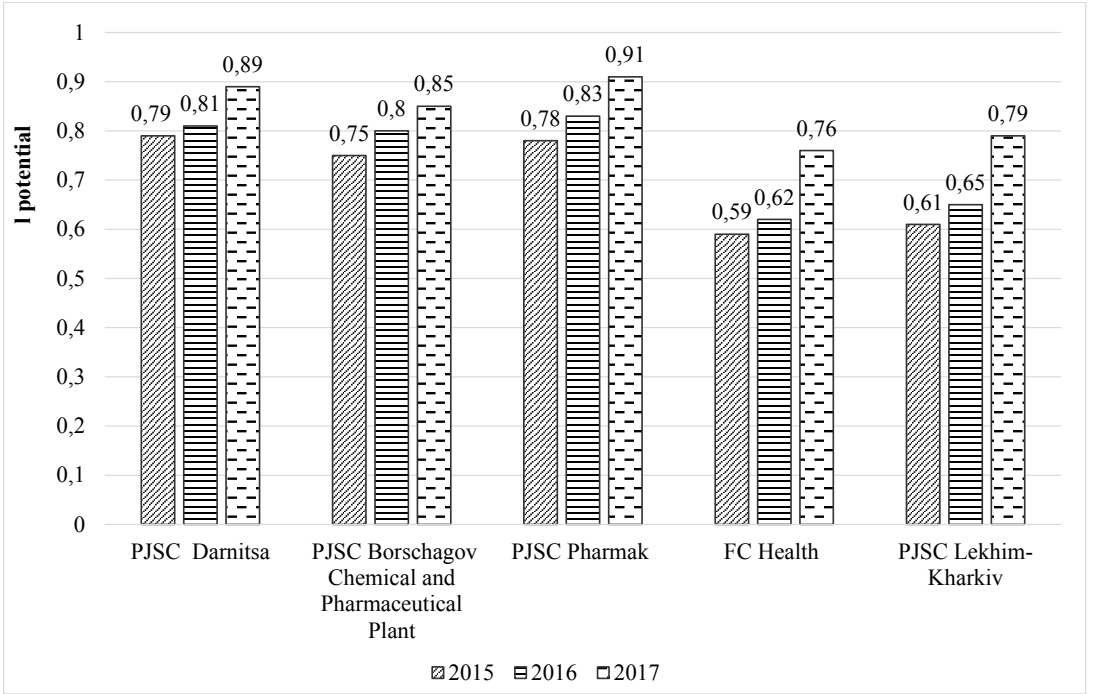

Fig. 2. Dynamics of integral index of logistics of FEA of the investigated PhEs

\section{Discussion}

Taking into account the theoretical positions and views of scientists, we consider it appropriate to use the definition of the logistics potential of a pharmaceutical enterprise subject to foreign economic activity, according to which it is a dynamically balanced system of resources and competencies, the effective use of which is based on the implementation of the optimization and integration properties of logistics (coordination of activities of functional units in organizing the movement of material, financial, information on resources per hundred actions of the logistic chain), determines the possibility of effective activity of the enterprise in the foreign market to ensure its development.

The proposed approach differs from the others $[4,20]$ by the complexity of the approach to the spheres of logistic activity of the enterprise, secondly, in the works [9] only quantitative indicators are taken into account.

As noted above, to date, insufficient attention has been paid to the problem under study. The vast majority of scientists investigate the level of logistic potential of the pharmaceutical enterprise as a whole, others have studied the potential of foreign economic activity of enterprises without taking into account the specificity of the pharmaceutical enterprise, its social orientation and the features of storage and transportation of finished medicines.

The proposed methodology differs from the existing ones and the set of indicators used to assess the level of potential. The obtained results allow us to conclude that the logistics of foreign economic activity of the studied domestic PhEs is quite different, since the value of integral indicators ranges from 0.59 to 0.91 .

Scale of assessment of the status of FEA logistics by the magnitude of the integral indicator has the following ranges: from 0 to 0.25 - unsatisfactory level of logistics of FEA; from 0.26 to 0.50 - average level of foreign trade logistics); from 0.51 to 0.75 - the level of foreign trade logistics is above average; from 0.76 to 1 - high level of FEA logistics.

Based on the calculations, the state logistics FEA any of the studied pharmaceutical enterprises can be described as high. Positive trend has all investigated pharmaceutical enterprises, rather high indicators are characteristic for PJSC "Pharmak", PJSC "Darnitsa" and PJSC NPC "Borschagovsky HFZ".

Therefore, we can conclude that the need to take measures to improve the level of logistics FEA at domestic pharmaceutical enterprises logistic potential, like all types of potentials inherent in AF, is formed under the influence of a large number of factors that exert both positive and negative effects, as well as constantly changing, which include not only the internal environment (the size of the pharmaceutical enterprises, the range of drugs manufactured enterprises, infrastructure 
development, etc.) and macroenvironment (demand, entry into the pharmaceutical market, competitors, etc.).

\section{Conclusions}

1. The definition of "logistics potential of foreign trade activity of pharmaceutical enterprise" is defined, under which it is expedient to understand a dynamically balanced system of resources and competencies, the effective use of which is based on the realization of optimization and integration properties of logistics (coordination of activity of functional units during the organization of movement of material, financial resources, by stages of the logistics chain), determines the possibility of effective activity of the enterprise in the foreign market to ensure its development.

2. A system of indicators has been developed to determine the level of development of logistics potential of foreign economic activity of a pharmaceutical enterprise. Thus, the logistics potential of a foreign trade activity of a pharmaceutical enterprise consists of the logistics potential in the sphere of export and the potential of logistics in the sphere of import. Quantitative indicators for measuring the potential of logistics in the export field include export volumes, number of partners and number of export operations; quality indicators include the level of logistical services, the rate of fulfilment of contractual obligations (in terms of quality, time, quantity) and the breadth of coverage of the markets for pharmaceutical products. Quantitative indicators for measuring the potential of import logistics include import volumes, number of partners, and number of export operations; to quality indicators - the level of logistic service, the rate of fulfilment of contractual obligations (in quality, time, quantity).

3. A system of indicators has been developed to determine the proposed methodology for evaluating the logistics potential of a foreign trade activity of a pharmaceutical enterprise, which takes into account the normative and real level of its development and the synergy coefficient.

4. The scale of estimation of the state of logistics of FEA by the magnitude of the integral index is offered, which allows to estimate the level of development and to develop directions of improvement on its basis.

\section{Conflict of interest}

No conflict of interest.

\section{References}

[1] Rushton, A., Croucher, P., Baker, P. (2014). The Handbook of Logistics and Distribution Management. Understanding the Supply Chain. Kogan Page, 2014. Available at: https://www.academia.edu/28639307/The_handbook_of_Logistics_and_ Distribution_ManageMent_5th_EDItION_Logistics_Distribution_MAnAgEMEnt_THE_HANDBOOK_OF_and_i

[2] Sturm, M., Junghanns, J., Stefan M. (2013). Schröder Taking logistics services' sales to the next level with better sales communications. Accenture, 1-16.

[3] Pelenskyi, P. O. (2012). Spetsyfika lohistyky pry zdiisnenni zovnishnoekonomichnoi diialnosti (ZED) pidpryiemstvamy Ukrainy. Naukovyi visnyk Lvivskoho natsionalnoho universytetu veterynarnoi medytsyny ta biotekhnolohii im. Gzhytskoho, 14 (2 (4)), 80-86.

[4] Pylypenko, A. A., Pospielov, O. M. (2008). Lohistychnyi potentsial pidpryiemstva: obmezhennia, metodyka otsiniuvannia ta orhanizatsiia upravlinnia. Visnyk ekonomiky transportu i promyslovosti, 21, 60-64.

[5] Piven, O. P., Slipchenko, H. D. (2018). Analiz konkurentnoho seredovyshcha na ukrainskomu rynku likarskykh preparativ. Aktualni problemy rozvytku haluzevoi ekonomiky ta lohistyky. Kharkiv: NFaU, 105-107.

[6] Piven, O. P., Tkachenko, I. V. (2016). Formuvannia merezhi vzaiemodiiuchykh na farmatsevtychnomu rynku pidpryiemstv na pryntsypakh marketynhu vzaiemovidnosyn. Menedzhment ta marketynh u skladi suchasnoi ekonomiky, nauky, osvity, praktyky. Kharkiv: NFaU, 426-427.

[7] Ponomarenko, M. S., Kabachna, A. V., Soloviov, O. S., Auhunas, S. V., Boryshchuk, V. O. (2016). Systemni pidkhody u stvorenni neobkhidnoho asortymentu likarskykh zasobiv dlia aptek simeinoi farmatsii ta aptek zahalnoho typu pry zakladakh simeinoi medytsyny. Farmatsevtychnyi chasopys, 2, 54-60.

[8] Pospielov, O. M. (2009). Orhanizatsiia lohistychnoho upravlinnia diialnistiu pidpryiemstva. Kharkiv, 264.

[9] Orlyk, I. O. (2012). Problemy ta priorytety rozvytku zovnishnoekonomichnoi diialnosti pidpryiemstv torhivli Ukrainy. Naukovyi visnyk NLTU Ukrainy, 22 (2), 216-221. 
[10] Kalyniuka, T. H., Parnavskoho, B. L. (Eds.) (2002). Pravovi, medychni ta farmatsevtychni aspekty stvorennia, realizatsii i zastosuvannia likarskykh zasobiv. Lviv, 216.

[11] Gudz, Y., Zadnipranna, T. (2016). Research methodology fundamentals of the ukrainian processing and manufacturing enterprises economic potential. Baltic Journal of Economic Studies, 2 (1), 32-38. doi: http://doi.org/10.30525/2256$0742 / 2016-2-1-32-38$

[12] Martowardojo, A. D. W. (2016). Optimizing Potential, Strengthening Resilience. Jakarta, 42.

[13] Nadvornaya, G., Klimchuk, S., Oborin, M., Gvarliani, T. (2016). Theory and Methodology of Appraisal of Enterprise Economic Potential. Economic and Social Changes: Facts, Trends, Forecast, (6 (48)), 70-90. doi: http://doi.org/10.15838/esc.2016.6.48.4

[14] Williams, J. C. (2019). Fulfilling our economic potential. Available at: https://www.bis.org/review/r190412a.pdf

[15] Farahani, R., Rezapour, S., Kardar, L. (2011). Logistics Operations and Management. Elsevier, 486.

[16] Ponis, S. T., Koronis, E. (2012). Supply Chain Resilience: Definition Of Concept And Its Formative Elements. Journal of Applied Business Research (JABR), 28 (5), 921-930. doi: http://doi.org/10.19030/jabr.v28i5.7234

[17] Ponomarov, S. Y., Holcomb, M. C. (2009). Understanding the concept of supply chain resilience. The International Journal of Logistics Management, 20 (1), 124-143. doi: http://doi.org/10.1108/09574090910954873

[18] Brandau, A., Tolujevs, J. (2012). Logistics Event Management - an overview of concepts to interpret logistical real time data. Proceedings of the 12th International Conference - Reliability and Statistics in Transportation and Communication. Riga, 171-178.

[19] Adamczak, M., Domanski, R., Cyplik, P., Pruska, Z. (2013). The tool for evaluating logistics processes. Scientific Journal of Logistics, 9 (4), 255-263.

[20] Corsten, D., Gruen, T., Peyinghaus, M. (2010). The effects of supplier-to-buyer identification on operational performance-An empirical investigation of inter-organizational identification in automotive relationships. Journal of Operations Management, 29 (6), 549-560. doi: http://doi.org/10.1016/j.jom.2010.10.002

Received date 26.08.2019

Accepted date 13.09.2019

Published date 20.09.2019
(C) The Author(s) 2019

This is an open access article under the CC BY license (http://creativecommons.org/licenses/by/4.0). 